\title{
The 2020 Cannabis Referendum: Māori Voter Support, Racialized Policing, and the Criminal Justice System
}

\author{
Craig Dempster ${ }^{1} \&$ Adele N. Norris ${ }^{2}$
}

\begin{abstract}
For the New Zealand 2020 cannabis referendum, 50.7\% of all voters rejected the creation of a legally regulated cannabis market and instead supported retaining the current prohibitionist policy. Although the referendum failed to pass, a majority of Māori voted in favour of cannabis law reform. This paper suggests that within the Māori community there is a more nuanced appreciation of the impact of policing cannabis. Māori perceive that greater harm is caused by the racialized policing of cannabis than by its usage. Following McCreanor, et al. (2014), this paper employs a thematic content analysis of the New Zealand Herald's coverage of the 2020 cannabis referendum to investigate the presence of race-based targeting/policing in discussions of the legislation. The results reveal that racial disparities emerged as secondary to framing both the impact of cannabis and the referendum as race-neutral, affecting everyone in society equally. This paper argues that the impact of the policing of this particular drug impacts Māori differently, wherein they bear the brunt of racialized policing. Thus, Māori possess a more sophisticated understanding that warrants consideration because it is inextricably linked to lived experiences of policing that differ from wider social narratives of policing and drug policy in New Zealand.
\end{abstract}

Keywords: 2020 cannabis referendum, racialized policing, drug policy, Indigenous and White bodies

\footnotetext{
${ }^{1}$ University of Waikato, Aotearoa New Zealand

${ }^{2}$ University of Waikato, Aotearoa New Zealand
} 


\section{Introduction}

The 2020 cannabis referendum was a Green Party Aotearoa initiative to create a legally regulated cannabis market and end the black market in cannabis sales. The proposal would have allowed people over the age of 20 to legally buy cannabis, up to 14 grams per day, from licensed vendors. The referendum results were that $50.7 \%$ of voters rejected reform and the current prohibitionist cannabis policy remains in place (Chui \& Hall, 2021). Support for cannabis law reform was significantly higher among Māori than among the general public. A 2019 opinion poll indicated 75\% of Māori supported cannabis legalization, and a 2020 poll found that $72 \%$ of Māori planned to vote to legalize cannabis use (Palmer, 2020; Theodore et al., 2021). Moreover, of the 45,500 special votes in Māori seats, $80 \%$ were in favour of legalization, notably higher than the $58 \%$ in favour among special votes from general seats (Elections New Zealand, 2020a, 2020b). While ordinary votes for the referendum from Māori and general electorates were placed in the same ballot box and unable to be separated, the special votes were counted separately, providing evidence that the views and understanding of the cannabis referendum differed considerably between Māori voters and general voters. Māori support for cannabis law reform deserves scholarly attention that is yet to be explored. When situated alongside recent events such as the extra-legal photographing of Māori youth by law enforcement, the Armed Response Team (ART) trials and the mass imprisonment of Māori in general (Norris \& Tauri, 2021), Māori support for reform implies that there is a more nuanced appreciation within the Māori community of the impact of policing cannabis. That is to say, there is much greater harm in the racialized policing of cannabis than the usage of it in Māori communities.

The New Zealand referendum proposed to transition the status of cannabis to full legality in one direct step, without allowing time for people to get used to intermediate reforms such as medical use or decriminalization. By contrast, some studies argue that the long-term availability of medical cannabis in certain US states played a role in subsequent successful referendums to end cannabis prohibition (Kilmer \& MacCoun, 2017). Another issue highlighted by Chui and Hall (2021) was the recent memory of the introduction of the Psychoactive Substances Act 2013, which created numerous legal outlets for selling substances in New Zealand. The concentration of outlets in impoverished areas rather than well-off suburbs drew considerable criticism. While one could argue that the placement of legal outlets in poorer communities relieves the legal financial burden 
associated with criminalization, a public backlash ended the experiment. Chui and Hall (2021) argued those against cannabis legalisation in 2020 were able to mobilize the fear in these communities by reminding people of the negative experiences in 2013.

\section{Racial Disparities, Discrimination and Policing}

Racial disparities between Indigenous and White people for drug arrests and sentencing has received little attention in discussions of the cannabis referendum. For communities with large Indigenous and Pacific populations, such as those whose children were the target of extra-legal photographing by law enforcement, experiences of surveillance and policing has been a continuous burden (Barnes et al., 2013; Norris \& Tauri, 2021). Reports emerged in early 2021 - and were confirmed by New Zealand police - that officers illegally recorded and uploaded images of Māori youth to an investigative app. While it is not illegal to take photos of individuals, the youth apprehended had not committed an offence nor were linked to an offence, but instead were racially profiled. The selectivity of photographic intel revealed levels of racialized surveillance Māori and Pacific communities experience that differs from wider society, which is further exemplified by the Armed Response Team (ART) trials of 2020 (Norris \& Tauri, 2021). The ART trials refer to the three-month trial period of armed police. The trial results showed that the team was primarily deployed in districts with high Māori and Pacific populations. Figures obtained by RNZ under the Official Information Act revealed that armed teams were deployed more times in an average week than Armed Offenders Squad (AOS) was sent an entire year. Instances with guns drawn on youth as young as 12 years old heightened the outcry from Māori communities to end the programme which lasted roughly three months (Norris \& Tauri, 2021).

Heightened policing of Māori was also identified in the New Zealand Health Survey 2012-13. The survey found that Māori were nearly twice as likely as non-Māori to be detained or targeted for cannabis (Parahi, 2020). Human rights lawyer, Dr Huhana Hickey, stated in a 2020 Stuff interview a month before the election,

It's [cannabis prohibition] a racist policy. It imprisons people of colour, it does not imprison white people... It needs to be legalised in order to remove the racism that exists in the incarceration of our people" (Parahi, 2020, para 1). 
Dr Hickey's comments reflect survey findings nearly a decade old. Her framing of the referendum that draws attention to stark racial disparities of how cannabis is policed represents a narrative and understanding that may differ from wider New Zealand society, yet important to discussions of drug policy.

Over the last decade, Indigenous scholars have called attention to sharp racial disparities in the criminal justice system in New Zealand (Andrai, McIntosh \& Coster, 2007; Cunneen \& Tauri, 2017; George, et al., 2014; George, et al., 2020; Jackson, 2017; McIntosh \& Workman, 2017; Quince, 2007; 2017; Webb, 2018). When considering the cannabis referendum within the context of the upsurge in Indigenous peoples' imprisonment, it is important to bring into view the racially-biased criminalization of cannabis. Māori comprise only $16 \%$ of the total population but represent over $55 \%$ of the prison population, and for Māori women, imprisonment is even higher (67\%) (George, et al., 2020). Deckert's 2014 article, Neo-colonial criminology: Quantifying the silence, points out an overall silence in mainstream criminology's inclusion of Indigenous people's experiences within the criminal justice system. Given that substantive attention in academic discourse is linked to public recognition, Deckert (2014) argues that the dearth of attention toward Indigenous people and the criminal justice system contributes to further marginalization, invisibility, and the reproduction of social inequality. Extant criminal justice scholarship advanced by Indigenous scholars has documented the silence alerting us to the historical trajectory of racialized surveillance and policing of Māori to the more recent phenomenon of Māori over-representation in the criminal justice system (see, Awatere, 1984; Cunneen \& Tauri, 2017; McIntosh \& Workman, 2017; Norris \& Tauri, 2021; Webb, 2017). These studies reflect a deliberate move away from mainstream, crime-centred analysis to critiques of the social structures that make mass imprisonment of Indigenous people predictable. Scholars engaging in these academic endeavours have taken a particular interest in elucidating the power dynamics of criminalization and policing of Indigenous identities at the intersection of class, gender, sexuality, spirituality, dis/ability and age (see, Driskill et al., 2011; George et al., 2020; McIntosh, 2005; Quince, 2007; Ross, 1998).

Intersectional theorists and Indigenous feminists and intellectuals have long recognized the intersecting nature of race, age, class, gender, sexual orientation, spirituality among others and argue that it must be considered in how different bodies are policed, marginalized and 
criminalized (see, Driskill et al., 2011; Jackson, 1987). Since the notion of deviance has always been applied to the historical treatment of gender and sexual orientation within criminology, a related goal of this discussion is to address the compounding effects of queer identities in the discussion of cannabis, policing, and criminalization. As Lindsay Kahle points out, in her 2018 article, Feminist and queer criminology: A vital place for theorizing LGBTQ youth, cultivating safe and accepting environments for transgender and queer youth has become a significant public health concern. Widespread discrimination renders gender-nonconforming bodies vulnerable to various levels of social policing, wherein they experience violence at heightened rates when compared to their cisgender counterparts (Hattery \& Smith, 2018). Thus, further theorization in the field of criminology, which has largely contributed to the erasure of trans, gender-nonconform, and queer experiences of discrimination and punishment as it relates to cannabis use, is required to address this gap (Kahle, 2018).

This paper examines mainstream newspaper coverage of the 2020 cannabis referendum with respect to acute racial disparities and other intersecting identities (e.g., LGBTQ) in the criminal justice system. It proceeds with a brief sketch of New Zealand drug policies with a particular focus on ways race and ethnicity have been intrinsic in the development of the legal framework employed to regulate certain drugs and narcotics. A discussion of racial disparities related to drug policies in the United States follows. The emphasis here is to elucidate links between drug policy, racial discrimination, and mass imprisonment. While the two countries differ in the ways colonization unfolded, critical criminal justice scholars have repeatedly called attention to the impact of criminalizing narratives around Indigenous and Black bodies in the creation of crime policy, in particular drug policies that led to the astronomical surge in incarceration rates. The paper concludes with a discussion of the broader implications of cannabis reform on racially marginalized groups, centring what informed insight from Māori voters and the broader community offers to discussions of drug policy reform and the broader criminal justice system.

\section{The History of New Zealand Drug Policy}

Drug prohibition in New Zealand came into existence with the implementation of the Narcotics Act 1965. Prior to 1965, New Zealand had gradually created a comprehensive legal framework to regulate certain narcotics. The first piece of legislation, the Opium Prohibition Act 1901, was 
intended to prevent the smoking of opium by the Chinese community in New Zealand. The policy expanded police powers to search, without a warrant, any Chinese who owned or leased property (Law Commission, 2011). The implementation of this policy mirrored the restrictions on opium use in the United States by allowing the police to target and monitor Chinese New Zealanders. Such policy created a perception that opium use was a racebased social issue that required a deliberately targeted solution (Brown, 2002). New Zealand's drug policy changes in the early 20th century reflected the gradual development of international conventions in 1912 and 1924, which led to the Dangerous Drugs Act 1927. This act created regulatory frameworks around the manufacture and supply of various narcotics such as opium and cannabis (Brown, 2014; Law Commission, 2011). According to Brown (2014), this legislation was created solely to align New Zealand law with global norms and to signal that New Zealand intended to comply with international conventions. Within New Zealand itself, drug use was widely regarded as unproblematic, and at this stage, drug consumption was not considered a social issue (Brown, 2014; Law Commission, 2011). The regime created by this legislation did not prevent the use of drugs completely, instead, drugs such as heroin and cannabis were widely available on prescription for medical reasons. During the 1940s, New Zealand had amongst the highest per capita incidences of heroin use globally, and while a decision was taken to reduce the level of prescribed heroin, the drug was not regarded as a pressing social issue (Brown, 2014; Law Commission, 2011). By the beginning of 1955, the rate of heroin prescriptions had been considerably reduced, and in response to a request from the World Health Organisation, New Zealand ended the importation of cannabis, even though cannabis was not targeted (Brown, 2014; Law Commission, 2011).

\section{Drugs as a Social Issue}

The perception of drug use as a social issue began to develop during the 1950s and 1960s (Brown, 2014). These changes were rooted in the growth of the counterculture that emerged after the Second World War. This counterculture destabilized accepted cultural and social norms and provided a challenge to the establishment (Brown, 2014; Law Commission, 2011). This period coincided with the migration of Māori from rural New Zealand into urban areas. In 1946, just 26\% of Māori lived in towns and cities but by 1966 this figure had more than doubled, reaching 62\% (Awatere, 1984). Māori became an increasingly visible presence within urban centres, and 
this immediately led to an increase in the number of Māori apprehended by the police at levels over and above the proportion demographic trends would suggest (Awatere, 1984; Corrections, 2007; Shilliam, 2012). The adoption of the Narcotics Act 1965 was the response from police and policymakers, reframing drugs as a matter of social/public concern, leading to the construction of narcotics as a serious threat to civil society.

It is important to note that this reframing coincided with heightened racial politics in the United States. Presidential rhetoric around drug use began to target Black American communities and inner-cities as primary locations of drugs and drug-related violence (Alexander, 2012; Norris \& Billings, 2016). This framing occurred during a time of cutting-edge activism in both New Zealand and the United States (Awatere, 1984; Norris \& Billings, 2016; Walker, 1990). With the rise of the Black Power Movement and Black racial uprisings receiving global attention, the United States' vilification of protesters as criminals facilitated the process to enact racially-biased drug policies (Alexander, 2012; Shilliam, 2012). Similar to the United States, the shift to enact drug policies in New Zealand, with a specific target population, radically altered both the powers of the police and judicial system (Brown, 2014). Brown (2014) argues that the significance of the shift lies in how it altered the burden of proof. Previously, police were required to prove suspects were aware they were in possession of illicit narcotics in instances where someone was unknowingly in a vehicle with drugs. Now accused individuals were required to prove they did not know they were in possession of illicit narcotics (Brown, 2014; Law Commission, 2011). Additionally, individuals in possession of illicit narcotics above a certain amount were automatically deemed to be in possession with intent to supply, which carried harsher penalties, and again the onus was incumbent on the individual and not the police to prove they were not guilty (Brown, 2014; Law Commission, 2011). The Narcotics Act 1965 also expanded police powers to conduct a search on any individual they considered may be in possession of illegal drugs without proof (Brown, 2014; Law Commission, 2011).

The Misuse of Drugs Act 1975 superseded the Narcotics Act 1965. The act retained the fundamental features of the former law, but increased State controls as tools to prevent illegal drug use with the official aim to prevent harm to individuals and society by restricting the supply, manufacture, and consumption of illegal drugs within society (Ministry of Health, 2015). Under this law, drugs are deemed by the state as detrimental to both individual users and society with government figures estimating that drug use costs 
New Zealand $\$ 6.5$ billion a year (Ministry of Health, 2015). The framing of drug use as cost in dollars to the nation is a common tactic used by government agencies and police to indicate a definable measure of harm that can be quantified by those in favour of drug prohibition. Often this figure includes both harm that is directly related to drug use as well as the distinct harm that is directly related to drug prohibitionist policies such as the cost to the judicial system (Law Commission, 2011). This approach often conceals the harm caused by drug prohibition where certain populations, whether drug use is present or not, have continuously been targets of policies that inflict state-sanctioned harm and trauma that they would otherwise not encounter. Moreover, overstating the harm of drug use to strengthen the narrative used to construct drug usage as a costly, harmful, and negative activity is a race-neutral approach to implementing racially-biased policies (Tonry, 2011).

Framing drug use as a cost to society expanded during the 1970s as part of the global 'War on Drugs' initiated by the United States (Alexander, 2012; Fordham, 2020; Tonry, 2011). This 'war' specifically targeted both those opposed to the Vietnam War and Black Americans (Fordham, 2020). It created a public perception that left-wing activists and Black civil-rights activists were associated with illegality, wherein they became subsumed in the framing of drug users as dangerous social deviants (Fordham, 2020). The Nixon administration constructed a powerful ideological framework that still underpins the societal imagination and construes drug users as dangerous, deviant, criminal, and Black who require social sanction and control (Fordham, 2020; Norris \& Billings, 2016).

\section{The U.S. War on Drugs and Racial Disparities}

The astronomical rise in the imprisonment rate in the United States under the Reagan administration as part of the War on Drugs has received ample attention. Scholars have long examined vast racial disparities driven by the 1986 federal law generally referred to as the "100-to-1 law," which punished the sale of crack as severely as sales of a hundred times larger amounts of powder cocaine (Alexander, 2012; Provine, 2007). What this means is that five grams of crack cocaine sold, a low-level street transaction, was given the same penalty as the sale of a half-kilogram of powder cocaine, a high-level distribution (Alexander, 2012; Hattery \& Smith, 2018; Tonry, 2011). This is well impressed upon the public's awareness of the racial groups associated with each drug without explicitly stating it (Welch, 2007). As Hattery and 
Smith (2018) point out, the sentencing disparity enacted at the height of the war on drugs era was rationalized by evoking racialized myths around Black bodies as dangerous and criminal (Tonry, 2011).

The crack to powder cocaine distinction drove racial disparities in conviction and sentencing. For example, in 2006, $82 \%$ of individuals sentenced under federal crack cocaine laws were Black. Only $8.8 \%$ of White people were sentenced under the same law, even though more than twothirds of people who use crack cocaine were White (Tonry, 2011). Two decades after the 1986 "100-to-1 law", the United States sentencing commission found that sentences appear to be harsher and more severe for racialized minorities than for White individuals under this law. Unlike the meth epidemic, which was framed as a public health concern,

the 'crack epidemic' was created as a tool to police Black bodies and to effect a War on Black bodies that is deliberate and built upon stereotypes and myths about drug use (Hattery \& Smith, 2018, p. 67).

For example, in 1978, approximately $80 \%$ of drug arrestees were White. After the Reagan administration expanded the 'war on drugs', Black people constituted over $40 \%$ of drug arrests in 1988, up from less than $20 \%$ a decade prior. As Tonry (2011) explains, at no point in time have Black people used or sold drugs at rates higher than White people, but they are targeted more and when arrested they are dealt with more harshly. Essentially, the 'war on drugs' was a war on Black bodies evidenced by the racial disparities found in the ways these drugs were policed. Adult drug arrests per 100,000 Americans in 1980 stood at 367 for Whites and 684 for Blacks. By 2002 the arrests for Whites increased to 658, a growth rate of $70 \%$, and to 2,221 for Blacks, a 225\% growth rate (Tonry, 2011). Recognizing sharp racial disparities illuminate different communities experiences with various levels of engagement with law enforcement that inform their understanding of surveillance and policing that is highly contextualized and politicized, which is important to capture.

\section{Methodology}

Since the late 1990s, an increasing amount of scholarship has sought to examine public opinion around cannabis legalization. Much of this work has taken a rhetorical approach, examining ideological dilemmas rooted in 
cultural and political history. For example, medical cannabis, given its highly contested and unconventional view as a treatment, has drawn considerable debate globally. Recent examinations exploring the power dynamics influencing medical cannabis framing and related policies have often relied on content analysis of print media coverage (see, Gunning $\&$ Illes, 2021; Halvorson et al., 2018; Lewis, Broitman \& Sznitman, 2015; Monaghan, Wincup \& Hamilton, 2021; Ryan, Smeltzer \& Sharts-Hopko, 2020; Sznitman \& Lewis, 2015). Within the New Zealand context, scholars have long examined the social construction of Māori in relation to White/Pākehā in crime-related coverage in print media (Barnes et al., 2012; Hodgetts et al., 2005; Maydell, 2018; McCreanor et al., 2014; Spoonley \& Hirsh, 1990; Walker, 1990). McCreanor and colleagues (2014) use a content, thematic/discursive analysis to examine crime coverage from various frames. The authors found that the coverage of White perpetrators of crime against Māori often valorized the perpetrator, while Māori, even in non-crime stories, were positioned as a threat. Allen and Bruce's (2017) examination of news media representation of events from a Pacific, lower-socio-economic community in South Auckland parallels McCreanor and colleagues' (2014) study. The authors found that the media marked 'differences' and sent the message that South Auckland, with its large non-Pākehā population, was a dangerous place through tactics that racialized crime. The amount of time devoted to discussing Pacific perpetrators versus White ones and the different language used were strategies used to facilitate the racialization of crime and problem areas. These studies come nearly 25 years after Ranginui Walker's 1990 study of the role of the press in defining Pākehā perceptions of Māori, suggesting very little has changed in ways criminalizing narratives are fashioned around racially marginalized groups. Print media, in particular newspapers, have remained a prime site for analysis around various cannabis debates and crime rhetoric (Felson, Adamczyk \& Thomas, 2019). The New Zealand Herald is easily the country's most widely-read newspaper, in both its print (584,000 readers per week) and online versions (1.6 million site visitors per week) (Roy Morgan, 2021).

This current study, following McCreanor and colleagues' (2014) methodology, employs a content/thematic analysis, which is suitable for counting and identifying common themes, concepts, language and structure. Articles from the New Zealand Herald published between September 2019 and October 2021 were selected as ideal for analysis as the timeframe covers rhetoric one year before and one year after the cannabis 
referendum. The keywords 'cannabis', 'referendum', 'Māori', 'White/Pākehā', 'racial disparity', 'legalization', and 'racism' were used for the initial search. As themes emerged, the search expanded to explore other themes such as 'queer', 'gay', 'harm'. As stated earlier, the inclusion of gendernonconforming bodies is a related goal that warrants special attention. Themes of queer identities were considered given that the intersectional nature of different bodies with race and ethnicity is frequently associated with chronic levels of policing and cannabis use.

The initial search produced 218 articles. A third of the articles were duplicates and omitted from the sample. A total of 56 articles were examined. Of those, it is important to note that 19 articles were primarily concerned with medical cannabis and fell beyond the scope of analysis. The final sample that fit the criteria for examination consisted of 37 articles. Over twothirds of the articles (26 articles/70\%) were published 13 months before the referendum, while the remaining 11 articles (30\%) were circulated in the 12 months after the referendum.

\section{Analysis}

Results revealed a majority of the articles were written conveying a highly normative perspective; a perspective Barnes and colleagues (2012) describe as presenting Pākehā as the norm. Māori were acknowledged in nine (25\%) articles. Of the remaining 28 (75\%) articles, race, ethnicity, or other social groups (e.g., queer, LGBTQ+) were not mentioned. Of the articles acknowledging Māori, nine articles acknowledged that cannabis and drug legislation were affecting Māori disproportionately due to structural racism, in general. Details relating to how historical or contemporary events of chronic policing and criminalization of Māori have led to high imprisonment rates, for example, were missing. Conversely, only one article mentioned White/Pākehā New Zealanders, stating that in their 20s White/Pākehā are amongst the highest users of cannabis in New Zealand along with Māori.

Another emergent theme found in 11 articles (32\%) was the framing of cannabis use as a health issue rather than a criminal justice issue. Important to note is that five (14\%) articles framed the proposed cannabis legislation as a criminal justice issue. Only one article was explicitly against legalization, while $43 \%$ were for legalisation. Fifty-four percent of the articles took no position on the outcome, while $24 \%$ attempted to strike a balanced tone by examining the advantages and disadvantages on both sides of the debate. 
Figure 1. Results content of newspaper articles on cannabis referendum

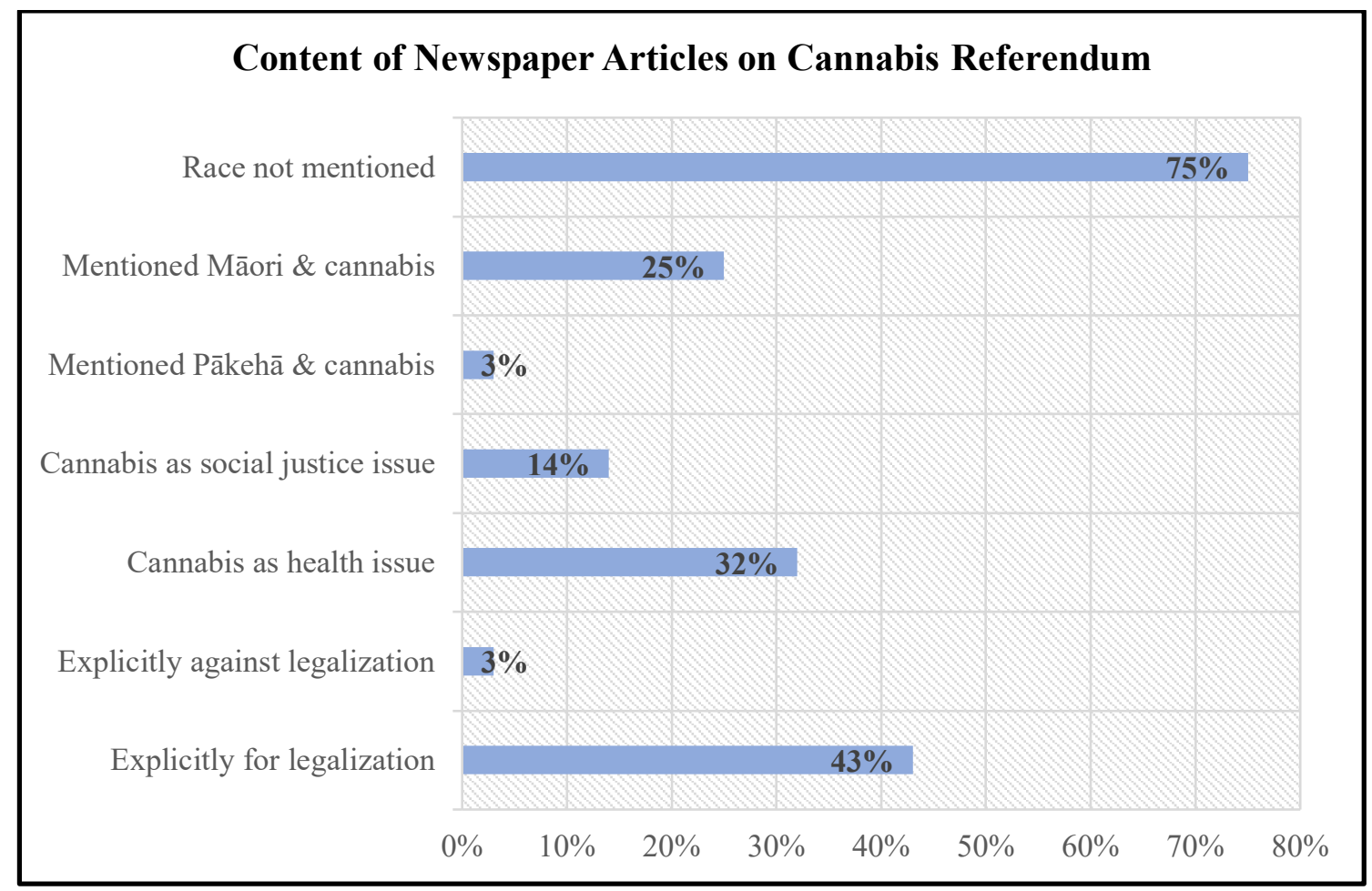

A secondary theme that deserves consideration is the referencing of gangs. Gangs were mentioned in two articles with the focus on how the proposed legislation would undermine the influence of gangs in the drugs market, thus suggesting laws prohibiting cannabis led to more social harm. Important to note is that race/ethnicity was not associated with the coverage of gangs. A total of five (14\%) articles presented a legalized and regulated cannabis market as a positive benefit for society as a whole. In these discussions, cannabis was presented as if all members of society experienced equal levels of suspicion, policing, and criminalization. Societal benefits included increased taxation from the legalized product.

The overarching narrative around the cannabis referendum emphasized the technical and procedural measures, such as minimum purchase age, how many grams an individual can purchase a day, and how a regulated market should be structured. Racial disparities with regard to how racial groups are policed in general received less attention and lacked nuance. Queer communities, who are more likely to suffer the negative consequences through criminal convictions and arrests for possession, did not emerge in the discussion. This absence deserves attention given the 
growing scholarship on how gender-nonconforming bodies are policed more harshly and to shed light on the compounding nature of social identities.

\section{Discussion}

The analysis reveals that racial disparities received limited attention in newspaper articles around the cannabis referendum. When systemic factors were mentioned, the discussion did not move beyond a simple statement of racism to specific ways racialized bodies have been policed and criminalized. This is an interesting finding given the growing discussions of state violence in the wake of the high imprisonment rate of Indigenous people. Since the 1980s, Indigenous scholars have examined mass media portrayals of Māori as a threat in comparison to White/Pākehā (Elers \& Elers, 2017; Hodgetts, et al., 2005; MacDonald \& Ormond, 2021; McCreanor et al., 2014; Walker, 1990). McCreanor and colleagues' 2014 article, The Association of Crime stories and Māori in Aotearoa New Zealand Print Media, maintains that the mass media remain central to the study of institutionalized racism given its power to produce and maintain social order. Mainstream media reporting that fails to include how different bodies, especially Indigenous bodies, are read and perceived by police and broader society continue to perpetuate criminalizing narratives around certain bodies (Indigenous) while exonerating others (White). Presenting the impact of decriminalizing cannabis that does not reflect how the drug is policed in different communities actively ignores decades of empirical evidence explaining this phenomenon.

Moana Jackson's 1987 seminal publication, The Māori and the Criminal Justice System: A New Perspective, He Whaipaanga Hou, locates the criminal justice system as a part of wider social systems that reflect institutional racism. Employing the definition provided by the 1985 Report of the Māori Advisory Unit of the Department of Social Welfare, Jackson defines institutional racism as "the perpetuation of policies and practices which advantage Pākehās and disadvantage other racial groups" (p.11). Jackson further explains that the effects of such policies, while viewed as normal or seemingly neutral societal operations, create "stereotyped expectations that justify unequal results; unequal results in one area foster inequalities in opportunity and accomplishment in others; the lack of opportunity and accomplishment confirm the original prejudices or engender new ones that fuel the normal opportunities generating unequal results" (p. 12). 
While Moana Jackson remains a preeminent voice in this field of study, activism emerged in direct response to Māori criminalization, which began to increase in the 1960s (Awatere, 1984; Shilliam, 2012). However, it was not until the early 1970s that academics began to take note and consider these rates of criminalization as problematic (Awatere, 1984; Corrections, 2007; Jackson, 1987). Within the last two decades, academic scholarship exploring the chronic policing of Māori as institutional racism has expanded (Cunneen \& Tauri, 2017; Deckert, 2014; George, et al., 2014; Quince, 2007; Staats et al., 2015; Tauri, 1999; Webb, 2009). Most recently, Oliver Sutherland's 2020 book, Justice and Race: Campaigns against Racism and Abuse in Aotearoa New Zealand, chronicles the mass criminalization of non-Pākehā people during the 1960s 1970s, which expanded with the creation of an oppressive police task force - formed in 1974 to combat street violence in Auckland.

In response to calls to address institutional racism, particularly in the criminal justice system, certain measures have been taken. For example, in 2019, drug policy was altered to restrict prosecution for drug possession to only those cases deemed to be in the public interest, however; the number of prosecutions only fell slightly from 1,247 in 2018/19 to 1,096 in 2019/2020 (NZ Drug Foundation, 2020). The 2019 drug policy was designed to reduce the number of individuals harmed through prosecution for drug possession, to mitigate one of the most criticized harms caused by drug prohibition. This goal seems to have been missed as the total prosecution rate for Māori of all minor drug offences increased from 1,350 to 1,537 (NZ Drug Foundation, 2020). The increase indicates the difficulties in reducing structural violence towards Māori, as racism is so entrenched that tweaks to the law still work to the benefit of White bodies. This paper argues that the failure to see substantial changes with the enactment of legislation designed to mitigate institutional racism reflects how deeply racism is rooted within institutions and how it hinges on embedded racialized narratives and stereotypes.

It is widely known that narratives of criminality, such as the noble savage, associated with Indigenous peoples had become the dominant social norm within New Zealand since the 1800s (Awatere, 1984; Lewis et al., 2020; McCreanor et al., 2014). Imagery of immorality as central to Māori life proved highly durable through the years and has been adapted to contemporary settings where it is still a powerful influence (McCreanor, 1997). The power of such imagery is easily observed with ways Māori social justice movements 
have been undermined through the deployment of rhetorical strategies by mainstream media outlets and the state that consistently construct Māori as deviant (Barnes, et al., 2012; Maydell, 2018; McCreanor et al., 2014; Walker, 1990). This association is particularly salient in the construction of gangs as being associated primarily with Māori and the main source of drug supply in the country (Lewis, et al., 2020; McCreanor et al., 2014; Ministry of Health, 2015; Morrison, 2009). Reporting crime by relying on racist tropes has been a consistent strategy applied when the perpetrator is Māori but this is not the case with White perpetrators (Maydell, 2018). Also, the trend to exclude White people from crime narratives is just as powerful in the construction of the criminal as Indigenous.

As stated earlier, the racialization of drug use in the United States during the 1980s was promoted at the highest levels (Hattery \& Smith, 2018; Norris \& Billings, 2016; Tonry, 2011). Presidential rhetoric in combination with the mass media primed the public to criminalize Black bodies, specifically males, by proxy of crack cocaine as the greatest threat to the country. Large urban areas and narratives of babies born addicted to crack cocaine dominated presidential rhetoric around crime control beginning in the late 1960s, when Civil Rights bills were being passed (Norris \& Billings, 2016). According to Alexander (2012), after the global coverage of the Civil Rights and Black Power movements of the 1960s and 1970s, respectively, policymakers capitalized on the images of large crowds of predominantly Black protesters, stoking the fears of White people. Absent from presidential rhetoric in framing the plight of inner-cities was the failure of public policy, decades of racist redlining, and government neglect (Hartnett, 1993; Norris \& Billings, 2016). Importantly, the exclusions of rural White areas and White bodies exonerated Whiteness from narratives of criminals and criminal activity (Norris \& Billings, 2018). Stereotypes generated and reinforced during the 1980s' 'war on drugs' perpetuated the narrative that every Black body, in particular a male body, is dangerous, which means that "every Black man should be suspected of a crime... need to be policed because all have the potential to threaten public safety" (Hattery \& Smith, 2018, p. 215). Similarly, in New Zealand, the reliance on racist tropes is so profound that it has become an embedded practice found in the framing of drug use or any social problem (McCreanor et al., 2014). The mere mention of drugs and crime generates a mental image of a particular person in society's consciousness whereby race/ethnicity does not need to be explicitly stated (Norris \& Billings, 2016). While this study's findings revealed that gangs were 
mentioned in the 2020 cannabis referendum reporting, a race/ethnic group was not associated with gangs. But was it necessary to explicitly state race or ethnicity to signal a particular group when mentioning gangs? It is this embedded imagery that influences the police and the government's chosen response to prohibition. Thus, emphasis is placed on the urgent need for stronger, effective laws and robust policing that target drug users while altering our judicial principles and undermining previously assumed universal human rights, thereby causing structural violence (McCreanor et al., 2014; Morrison, 2009). This understanding carries important implications why certain populations marked with the stigma of criminality would possess a more sophisticated understanding of the deployment of drug policies.

The 2020 cannabis referendum was an opportunity to mitigate some of the structural violence in how drug laws are enforced. Yet, when discussions do not highlight the racial disparities, drug policies are presented as neutral, affecting populations equally. Different bodies are at a higher risk of being policed. For example, people who engage in sex work whether legally or illegally are at higher risk of violence and policing that often gets overlooked. Gender-nonconforming, trans bodies, gender-fluid and LGBTQ+ people are important to recognize in this discussion, especially their invisibility. For instance, the representation of the queer community in the criminal justice system is largely invisible and not recognized in national statistics. In the United States, for example, the National Center for Transgender Equality in a 2015 report showed that $16 \%$ of transgender people and $21 \%$ of transwomen have been incarcerated in their lifetimes. Among Black transgender people, nearly half (47\%) have been incarcerated, a rate that is 10 to 15 percentage points higher than the rate for all Black people (Hattery \& Smith, 2018). This illustrates how disadvantages accrue and are worse for non-White people. As certain nonconforming bodies are more likely to experience incarceration, job discrimination, violent policing/harassment that leads to poverty and related consequences, it is imperative to capture these experiences in relation to drug policy and criminalization.

\section{Conclusion}

This study found that racial disparities in the criminal justice system, where Māori are represented at a rate four times their share of the population, did not receive substantial mainstream coverage of the 2020 cannabis 
referendum. Moreover, the findings revealed that media coverage did not correspond with or capture the greater support among Māori voters for law reform in the referendum. The question put before us is how drug policy influences racial disparities and the mass representation of Indigenous people in the criminal justice system and what we can learn from Indigenous and other communities who experience higher levels of policing of cannabis. To explore drug policy in the case of the cannabis referendum in ways divorced from race/ethnicity illustrates what Garrick Cooper (2022) describes as a marked feature in New Zealand: an entrenched resistance to discussing ways in which race and racism operate in New Zealand. In doing so, various forms of institutional racism remain unexamined, obscuring the process of how colonial forms of racial social control and policing survive and are revived.

As referenced earlier, research in the United States has long revealed that it was the strategic use of drug policies in the 1980s, drawing on criminalizing narratives of violence around Blackness, that drove massive racial disparities in drug arrests and sentencing that did not correspond with actual drug use and sale by race. The global influence of the United States 'war on drugs' has been recognized in New Zealand. How drug policy leads to disparate levels of policing among Indigenous and other marginalized bodies in New Zealand has not been explored in detail. This study suggests that the large support from Māori voters compared with general voters for the 2020 cannabis referendum has less to do with factors highlighted in the newspaper rhetoric around harm and social cost and more to do with the gratuitous racial inequalities for which they bear the brunt. Thus, large support from Māori voters signals a sophisticated understanding of the harm associated with the racialized policing of this drug is greater than the actual use of this drug in Māori communities.

\section{References}

Alexander, M. (2012). The new Jim Crow: Mass incarceration in the age of colorblindness. New Press.

Allen, J., \& Bruce, T. (2017). Constructing the other: New media representations of a predominantly 'brown' community in New Zealand. Pacific Journalism Review, 23(1), 225-244. DOI: 10.24135/pjr.v23i1.33 
Andrai, D., McIntosh, T., \& Coster, S. (2017). Marginalised: An insider's view of the State. State policies in New Zealand and gang formation. Critical Criminology, 25, 119-135. DOI 10.1007/s10612-016-9325-8

Awatere, D. (1984). Māori sovereignty. Broadsheet.

Bargh, M. (2020). The Māori electoral option: How can trends on roll choices be explained? MAI Journal, 9(3), 195-208.

Barnes, A. M., Borell, B., Taiapa, K., Rankine, J., Nairn, R., \& McCreanor, T. (2012). Anti-Maori themes in New Zealand journalism-toward alternative practice. Pacific Journalism Review, 18(1), 195-216.

Barnes, A. M., Taiapa, K., Borell, B., \& McCreanor, T. (2013). Māori experiences and responses to racism in Aotearoa New Zealand. MAI Journal, 2(2), 63-77. DOI: 10.20507/MAIJournal.2020.9.3.2

Brown, R. (2014). History never repeats. Matter of substance, 26(1). Available at $\quad$ https://www.drugfoundation.org.nz/matters-ofsubstance/archive/august-2014/does-history-repeat/

Brown, R. (2002). The opium trade and opium policies in India, China, Britain, and the United States: Historical comparisons and theoretical interpretations. Asian Journal of Social Science, 30(3), 623-656. DOI:10.1163/156853102320945420

Chiu, V., \& Hall, W. (2021). Was New Zealand's referendum to legalise cannabis premature? Drug and Alcohol Review, 40(6), 882-883. DOI: $10.1111 /$ dar. 13301

Cooper, G. (2022). Hidden beneath tiriti discourse. In A. Tecun, L. Lopesi \& A. Sankar (Eds.), Towards a grammar of race in Aotearoa New Zealand. Bridget Williams Books.

Corrections (2007). Over-representation of Māori in the criminal justice system: An exploratory report. Department of Corrections.

Cunneen, C., \& Tauri, J. (2017). Indigenous criminology. Policy Press.

Deckert, A. (2014). Neo-colonial criminology: Quantifying silence. African Journal of Criminology and Justice Studies, 8, 39-60.

Driskill, Q. L., Finley, C., Gilley, \& Morgensen, S. L. (Eds.). (2011). Queer Indigenous studies: Critical interventions in theory, politics, and literature. University of Arizona Press.

Elections New Zealand (2020a). Referendum results special votes breakdown Available at https://elections.nz/assets/2020-generalelection/Referendum-results-special-votes-breakdown.pdf 
Elections New Zealand (2020b). Referendum results ordinary votes. Available at https://elections.nz/assets/2020-generalelection/Referendum-results-ordinary-votes-breakdown10112020.pdf

Elers, S., \& Elers, P. (2017). Myth, Māori and two cartoons: A semiotic analysis. Ethical Space: The International Journal of Communication Ethics, 14(2-3), 42-51.

Felson, J., Adamczyk, A., \& Thomas, C. (2019). How and why have attitudes about cannabis legalization changed so much? Social Science Research, 78, 12-27. DOI:10.1016/j.ssresearch.2018.12.011

Fordham, A. (2020). The war on drugs is built on racism, It's time to decolonise drug policies. Available at https://idpc.net/blog/2020/06/the-waron-drugs-is-built-on-racism-it-s-time-to-decolonise-drug-policies

George, L., Ngamu, E., Sidwell, M., Martin-Fletcher, N., Ripia, L., Davis, R., \& Wihongi, H. (2014). Historical trauma and contemporary rebuilding for Māori women with experiences of incarceration. MAI Journal, 3, 183-196.

George, L., Norris, A., Deckert, A., \& Tauri, J. (Eds.) (2020). Neo-colonial injustice and the mass mprisonment of Indigenous women. Palgrave Macmillan.

Gunning, M., \& Illes, J. (2021). Coverage of medical cannabis by Canadian new media: Ethics, access, and policy. International Journal of Drug Policy, 97, 1-8. DOI:10.1016/j.drugpo.2021.103361

Halvorson, R. T., Steward, C. C., Thakur, A., \& Glantz, S. A. (2018). Scientific quality of health-related articles in speciality cannabis and general newspapers in San Francisco. Journal of Health Communication, 23(12), 993-998.

Hartnett, J. J. (1993). Affordable housing, exclusionary zoning, and American apartheid: Using title viii to foster statewide racial integration. New York University Law Review, 68(1), 89-135.

Hattery, A., \& Smith, E. (2018). Policing the Black body: How Black lives are surveilled and how to work for change. Rowman and Littlefield.

Hodgetts, D., Barnett, A., Duirs, A., Henry, J., \& Schwanen, A. (2005). Māori media production, civic journalism and the foreshore and seabed controversy in Aotearoa. Pacific Journalism Review, 11(2), 191-208. DOI: $10.3316 /$ INFORMIT. 123386942884966 
Kahle, L. (2018). Feminist and queer criminology: A vital place for theorizing LGBTQ youth. Sociology Compass, 12(3), 1-9 DOI: $10.1111 /$ soc4. 12564

Jackson, M. (2017). We have come too far not to go further. Counterfutures, 4, 27-51.

Jackson, M. (1987). The Māori and the criminal justice system: A new perspective, He whaipaanga hou. Available at https: / /www.ojp.gov/pdffiles 1/Digitization/108675NCJRS.pdf

Kilmer, B., \& MacCoun, R. (2017). How medical marijuana smoothed the transition to marijuana legalization in the United States. Annual Review of Law and Social Science, 13, 181-202.

Law Commission. (2011). Controlling and regulating drugs: A review of the Misuse of Drugs Act 1975. Available at https://www.lawcom.govt.nz/sites/default/files/projectAvailableFor mats/NZLC\%20R122.pdf

Lewis, N., Broitman, D., \& Sznitman, S. R. (2015). Medical cannabis: A framing analysis of Israeli newspaper coverage. Science Communication, 37(6), 675-702.

Lewis, C., Norris, A., Heta-Cooper, W., \& Tauri, J. (2020). Stigmatising gang narratives, housing, and the social policing of Māori women. In L. George, A. N. Norris, A. Deckert, \& J. Tauri (Eds.), Neo-colonial injustice and the mass imprisonment of Indigenous women (pp. 13-33). Palgrave Macmillan.

MacDonald, L., \& Ormond, A. (2021). Racism and silencing in the media in Aotearoa New Zealand. AlterNative: An International Journal of Indigenous Peoples, 17(2), 156-164. DOI: 11771801211015436.

Maydell, E. (2018). 'It just seemed like your normal domestic violence': Ethnic stereotypes in print media coverage of child abuse in New Zealand. Media, Culture \& Society, 40(5), 707-724.

McCreanor, T. (1997). When racism stepped ashore: Antecedents of antiMaori discourse in New Zealand. New Zealand Journal of Psychology, 23, 43-57.

McCreanor, T., Rankine, J., Moewaka Barnes, A., Borell, B., Nairn, R., \& McManus, A. (2014). The association of crime stories and Māori in Aotearoa New Zealand print media. A Journal of Social Anthropology and Cultural Studies, 11(1), 121-144. 
McIntosh, T. (2005). Maori identities: Fixed, fluid, forced. In J. H. Liu, T. McCreanor, T. McIntosh \& T. Teaiwa (Eds.), New Zealand identities: Departures and destinations, (pp. 38-51). Victoria University Press.

McIntosh, T., \& Workman, K. (2017). Māori and prison. In A. Deckert \& R. Sarre (Eds.), The Palgrave handbook of Australian and New Zealand criminology, crime and justice (pp. 725-735). Palgrave Macmillan.

Ministry of Health. (2015). National Drug Policy 2015 to 2020. Available at https://www.health.govt.nz/system/files/documents/publications/ national-drug-policy-2015-2020-aug15.pdf

Monaghan, M., Wincup, E., \& Hamilton, I. (2021). Scandalous decisions: Explaining shifts in UK medicinal cannabis policy. Addiction, 116(7), 1925-1933. https: / /doi.org/10.1111/add.15350

Morrison, B. (2009). Identifying and responding to bias in the criminal justice system: A review of international and New Zealand research. Available at www.justice.govt.nz/assets/Documents/Publications/Identifyingand-responding-to-bias-in-the-criminal-justice-system.pdf

Norris, A. N., \& Billings, J. (2016). Colorblind ideology, mass incarceration, and controlling racial images: An intersectional analysis of presidential rhetoric from 1969-1996. Journal of Ethnicity in Criminal Justice, 15(1), 78-98. doi/full/10.1080/15377938.2016.1256847

Norris, A. N., \& Tauri, J. (2021). Racialized surveillance in New Zealand: From the Tūhoe raids to the extra-legal photographing of Indigenous youth. Race and Justice. Online first. DOI: $10.1177 / 21533687211063581$

NZ Drug Foundation (2020). State of the Nation 2020. Available at https: / /www.drugfoundation.org.nz/assets/uploads/State-of-theNation-2020-WEB2.pdf

Palmer, S. (2020). New survey shows nearly three-quarters of Māori support legalising cannabis. Newshub, 1 July. Available at https://www.newshub.co.nz/home/politics/2020/07/new-surveyshows-nearly-three-quarters-of-m-ori-support-legalisingcannabis.html

Parahi, C. (2020). Cannabis referendum: Would legalisation change the 'race-based' targeting of Māori? Stuff, 4 September. Available at www.stuff.co.nz/pou-tiaki/300096454/cannabis-referendum-wouldlegalisation-change-the-racebased-targeting-of-mori

Provine, D. M. (2007). Unequal under law race in the war on drugs. University of Chicago Press. 
Quince, K. (2017). Rangatahi courts. In A. Deckert \& R. Sarre (Eds.), The Palgrave handbook of Australian and New Zealand criminology, crime and justice, (pp. 711-724). Palgrave Macmillan.

Quince, K. (2007). Māori and the criminal justice system in New Zealand. In J. Tolmie \& W. Brookbanks (Eds.), Criminal justice in New Zealand (pp. 333-358). LexisNexis.

Ross, L. (1998). Inventing the savage: The social construction of Native American criminality. University of Texas Press.

Roy Morgan (2021). Readership in New Zealand, 12 Months to June 2021. Available at http://www.roymorgan.com/industries/media/readership/readersh ip-new-zealand

Ryan, J. E., Smeltzer, S. C., \& Sharts-Hopko, N. C. (2020). Parents' experiences using medical cannabis for their child. Nursing Outlook, 68(3), 337-344. https://doi.org/10.1016/j.outlook.2019.12.004

Shilliam, R. (2012). The Polynesian Panthers and the Black Power Gang: Surviving Racism and Colonialism in Aotearoa New Zealand. In N. Slate (Ed.), Black Power Beyond Borders (pp. 107-126). Palgrave Macmillan.

Spoonley, P., \& Hirsh, W. (Eds.) (1990). Between the lines: Racism and the New Zealand media. Raupo.

Staats, C., Capatosto, K., Wright, R., \& Contractor, D. (2015). State of the science: Implicit bias review 2015. Kirwan Institute for the Study of Race and Ethnicity. Available at http://kirwaninstitute.osu.edu/wpcontent/uploads/2015/05/2015-kirwan-implicit-bias.pdf

Sutherland, O. (2020). Justice \& race: Campaigns against racism and abuse in Aotearoa New Zealand. Steele Roberts Aotearoa Ltd.

Sznitman, S. R., \& Lewis, N. (2015). Is cannabis an illicit drug or a medicine? A quantitative framing analysis of Israeli newspaper coverage. International Journal of Drug Policy, 26(5), 446-452. DOI: 10.1016/j.drugpo.2015.01.010

Tauri, J. (2017). Imagining an Indigenous criminological future. In A. Deckert, \& R. Sarre (Eds.), The Palgrave handbook of Australian and New Zealand criminology, crime and justice (pp. 769-783). Palgrave Macmillan. 
Tauri, J. (1999). Explaining recent innovations in New Zealand's criminal justice system: empowering Maori or biculturalising the state? Australian \& New Zealand Journal of Criminology, 32(2), 153167. DOI: $10.1177 / 000486589903200205$

Tonry, M. (2011). Punishing race: A continuing American dilemma. Oxford University Press.

Theodore, R., Ratma, M., Potiki, T., Boden, J., \& Poulton, R. (2021). Cannabis, the cannabis referendum and Māori youth: a review from a lifecourse $\quad$ perspective. Kotuitui, 16(1), 1-17. https://doi.org/10.1080/1177083X.2020.1760897

Walker, R. (1990). The role of the press in defining Pakeha perceptions of the Maori. In P. Spoonley \& W. Hirsh (Eds.), Between the lines: Racism and the New Zealand media (pp. 38-46). Heinemann Reed.

Webb, R. (2009). Māori, Pacific peoples and the social construction of crime statistics. Mai Review, 3(2), 1-4.

Webb, R. (2017). Māori experiences of colonisation and Māori criminology. In A. Deckert \& R. Sarre (Eds.), The Palgrave handbook of Australian and New Zealand criminology, crime and justice (pp. 683-696). Palgrave Macmillan.

Webb, R. (2018). Rethinking the utility of the risk factors and criminogenic needs approaches in Aotearoa New Zealand. Journal of Global Indigeneity, 3(1), Article 5.

Welch, K. (2007). Black criminal stereotypes and racial profiling. Journal of Contemporary Criminal Justice, 23(3), 276-288. DOI: $10.1177 / 1043986207306870$ 
This page is intentionally left blank. 